\title{
Visiones or superstitiones magicae? \\ Os mártires como agentes sobrenaturais \\ no cristianismo primitivo
}

\author{
Visiones or superstitiones magicae? Martyrs as \\ supernatural agents in the early Christianity
}

\section{Visiones or superstitiones magicae? Mártires como agentes sobrenaturales en el cristianismo primitivo}

\author{
Denilson Silva Matos*
}

\begin{abstract}
RESUMO
Este artigo pretende explorar a relação entre martírio e magia como um dos fatores para as perseguições aos primeiros cristãos no segundo século da era cristã. A combinação entre a construção da imagem do mártir e o crescente processo de repressão de práticas consideradas suspeitas e ameaçadoras por parte do império romano, em especial com o imperador Septímio Severo (193-211), contribuem para a possível relação. Ao enquadrar as práticas cristãs na categoria de superstitio e freelance expert em religião nos permite identificar o modo como os romanos viam os cristãos do império, a saber, como um grupo misterioso que possuía conhecimento de astrologia, magia e conceitos sobrenaturais.

Palavras-chave: Cristianismo Primitivo; martírio; mártires; magia.
\end{abstract}

\begin{abstract}
This article aims to explore the relationship between martyrdom and magic as one of the factors for the persecution of the first Christians in the second century of the Christian era. The combination of the construction of the martyr's image and the growing process of repression of practices considered suspicious and threatening by the Roman empire, especially with the emperor Septimius Severus (193-211), contributed to the possible relationship. By placing Christian practices in the category of superstitio and freelance expert in religion, it allows us to identify the way in which the Romans saw the Christians of the empire, namely, as a mysterious group that had knowledge of astrology, magic and supernatural concepts. Keywords: Early Christianity; martyrdom; martyrs; magic.

\section{RESUMEN}

Este artículo tiene como objetivo explorar la relación entre el martirio y la magia como uno de los factores para la persecución de los primeros cristianos en el siglo II de la era cristiana. La combinación de la construcción de la imagen del mártir y el creciente proceso de represión de prácticas consideradas sospechosas y amenazantes por el imperio romano, especialmente con el emperador Septimio Severo (193-211) contribuyen a la posible relación. Al colocar las prácticas cristianas en la categoría de superstitio y freelance expert, nos permite identificar la forma en que los romanos veían a los cristianos del imperio, es decir, como un grupo misterioso que tenía conocimiento de astrología, magia y conceptos sobrenaturales. Palabras clave: Cristianismo Primitivo; martirio; mártires; magia.
\end{abstract}

Doutorando em Ciências da Religião pela UMESP. Bolsista CNPq. E-mail: smdenilson@gmail.com 


\section{Introdução}

Não é incomum encontrarmos uma leitura do cristianismo primitivo que sugere uma isenção de processos sincréticos com a cultura greco-romana, privilegiando a ideia de total exclusão e participação de qualquer âmbito da cultura romana. Dessa forma, os primeiros cristãos tornam-se modelos ideias de um movimento "puro e simples", pacífico e ordenado.

Essa abordagem desconsidera os diversos conflitos, movimentos e, principalmente, um extenso corpus literário produzido pelos primeiros cristãos, a partir de critérios e fronteiras imaginárias entre listas de canônicos e listas de apócrifos; textos oficiais e textos proibidos; ortodoxos e heterodoxos. Essa leitura não é identificada apenas nos diversos grupos religiosos, ela também faz parte de departamentos acadêmicos que diferenciam o estudo do Novo Testamento, limitado aos textos canônicos, daqueles conhecidos como Cristianismo Primitivo, cujo corpus literário abarcaria desde os Pais da Igreja, Atas Martirológicas, Atos Apostólicos Apócrifos, hagiografia e iconografia cristã.

Um olhar mais acurado torna-se fundamental para não envolvermos um movimento que nasce plural, permeado de hermenêuticas sobre o que possivelmente fez e ensinou Jesus Nazareno - inclusive em concorrência umas com as outras -, num movimento ortodoxo, pronto, coeso, sem fissura, incongruência, polarização.

Essa tarefa se apresenta complicada ao passo que temos que lidar com fontes de variados gêneros literários e na longa duração. Nesse caso, se propomos olhar para o cristianismo primitivo como um movimento que se estabelece culturalmente por meio de interações discursivas e práticas com o seu entorno, como lidar com fontes que se constituem ao afirmar o contrário, ou seja, que propõem uma ruptura da participação, homologação e apropriação de discursos, topos literários e práticas já dadas culturalmente? É possível incluir o tema do martírio nesse processo de interação ou apenas como conflito? O martírio resulta de um confronto direto entre as pessoas que se dizem fiéis às suas normas e crenças religiosas e o/um império que exige coercitivamente o abandono de tais normas, e, no caso do cristianismo, a relação estabelecida entre cristãos e romanos nos quatro primeiros séculos da Era Cristã é constantemente retratada como conflituosa. Assim, é possível identificar fagulhas de religiosidade popular nas Atas e Narrativas martirológicas? Tais inquietações nortearão o percurso deste artigo. 


\section{Semen est sanguis christianorum ${ }^{1}$}

A principal imagem que cultivamos sobre os mártires do cristianismo primitivo é: homens e mulheres - cristãos confessos - sendo devorados por leões, queimados vivos, e dilacerados por soldados romanos como um espetáculo no famoso Coliseu. Contudo, a pesquisa acadêmica recente se dedica à demonstração de que a imagem que temos de cristãos constantemente perseguidos e martirizados é fruto de uma representação criada pela Igreja primitiva. Candida Moss (2013, p. 127), uma das principais pesquisadoras do assunto, atesta que:

A imagem dos cristãos amontoados em catacumbas ou reuniões secretas em casas um do outro humildemente observando dias santos e vivendo com medo da prisão, tortura e execução são onipresentes. Tudo a partir de Ben Hur, em A Paixão de Cristo, nos dá a impressão de que os cristãos viviam sob a constante ameaça de perseguição brutal, que eles eram forçados a viver e adorar em segredo, e que eles somente poderiam se comunicar uns com os outros usando senhas e símbolos secretos, tais como o peixe.

Em sua obra, a autora pretende demonstrar que tal representação é um mito criado pela Igreja, que houve perseguições locais e esporádicas, mas também longos períodos de liberdade e interação entre cristãos e romanos.

\section{Quais crimes cometeram os cristãos para serem perseguidos?}

Em seu artigo "Why were the Early Christians persecuted?", Geoffrey Ernest Maurice de Ste. Croix (1963, p. 6-38) argumenta acerca dos motivos que levaram à perseguição dos cristãos, supondo os procedimentos legais nos quais os romanos se basearam para julgá-los. Além disso, ele procura analisar a perseguição a partir da ótica "de baixo", dos perseguidos, ou seja, como os primeiros cristãos interpretaram tais perseguições e consequentemente a morte. O autor (CROIX, 1963, p. 6) propõe três fases distintas para entendermos as perseguições aos cristãos:

A primeira termina pouco antes do grande incêndio de Roma em 64; a segunda começa com a perseguição que seguiu o incêndio e continuou até 250; e a terceira abre com a perseguição sob Décio em 250-1 e dura até 313 - ou, se levarmos em conta as atividades anticristãs de Licínio em seus últimos anos, até a derrota de Licínio por Constantino em 324.

\footnotetext{
Semen est sanguis christianorum (O Sangue dos cristãos é semente) foi uma máxima dita por Tertuliano (Apologeticum 50,13) por ocasião das perseguições à igreja no segundo século da era cristã. Tal máxima tornou-se símbolo da força que o sofrimento dos mártires possuía no processo de conversão dos primeiros cristãos.
} 
Não se sabe a respeito de perseguições até o ano de 64, e tal prática só veio a existir até aquela executada por Décio. Entre 64 e 250, existiram apenas perseguições isoladas e locais, sublinha o autor. A perseguição geral de Décio deve ter durado pouco mais do que um ano, e aquela de Valeriano de 257-9, pouco menos que três anos. A terceira e última, denominada de "grande perseguição", sob Diocleciano em 303, durou dois anos, no Oeste. Aconteceram muitas outras locais, mas houve também longos períodos durante os quais os cristãos desfrutaram de paz completa sobre a maior parte do império.

Da mesma forma, Jean Comby (1993, p. 41) desconhece que os cristãos foram perseguidos de maneira contínua durante os três primeiros séculos. $\mathrm{O}$ autor fundamenta sua afirmação nos escritos de historiadores romanos como Tácito e Plínio, o Moço, que não expressam diretamente indícios de perseguição geral contra os cristãos. Para ele, tal prática parece não ter saído dos limites romanos, e foi estrategicamente usada por Nero para despistar os rumores que ele mesmo teria sido o responsável pelo incêndio de Roma, a fim de reconstruí-la conforme seus gostos arquitetônicos. Assim relata Tácito: 'Nero, para desviar as suspeitas, procurou culpados e castigou com as mais terríveis penas a certo grupo, já odiado por suas abominações, que o vulgo chamava cristãos". Os dois primeiros séculos, afirma Comby, "não conheceram uma perseguição geral, nem tampouco uma lei bastante precisa em relação aos cristãos. Elas continuam a apresentar um caráter local e são muito limitadas no tempo" (COMBY, 1993, p. 41-43).

Nesse caso, não há um conjunto de leis específicas promulgadas a respeito dos cristãos e sua devoção. O que temos são alguns fragmentos de julgamentos e correspondências pessoais, como no caso da carta de Plínio, o Moço, governador da Bitinia (Norte da Ásia Menor), ao imperador Trajano, em 111 d.C. A carta revela a incerteza do jovem governador em relação ao que fazer com os cristãos que persistiam em sua fé, situação que cada vez mais crescia em sua província (GONZÁLES, 1995, p. 62). A quais procedimentos ele deveria recorrer para julgar os cristãos? Por esse motivo, solicita uma instrução por parte do imperador Trajano, cuja resposta foi breve e taxativa, afirmando que não se deve nem procurar os cristãos, nem aceitar as denúncias anônimas. Contudo, é necessário condenar aqueles que persistem dizerem-se cristãos (GONZÁLES, 1995, p. 64).

\section{Se não havia perseguições generalizadas, como explicar a grande produção de textos e adeptos do martírio?}

A grande proliferação de textos martirológicos e, consequentemente, de mártires no cristianismo primitivo é fruto, também, de uma construção 
discursiva. Os primeiros cristãos identificaram seu sofrimento com o sofrimento de Jesus, o que conferiu ao martírio e ao mártir um status diferenciado do cristão "comum" na hierarquia eclesiástica e até mesmo na celestial. Para Moss (2010, p. 3), “o mártir segue a Cristo, tanto literalmente como literariamente". Essa afirmação baseia-se na prerrogativa de que o mártir é relido por intermédio da tradição sobre a morte de Jesus, possibilitando identificar tanto a diversidade de representação dos mártires como as diferentes e variadas formas de recepção acerca da morte de Cristo pelas diversas comunidades cristãs espalhadas pelo mundo mediterrâneo.

Em busca da gênese de tal comportamento cristão, Moss afirma que "muito antes das perseguições de Décio e Diocleciano, cristãos começaram a identificar seus próprios sofrimentos, sejam eles 'verdadeiros' ou 'percebidos', com aqueles dos sofrimentos do Messias deles" (MOSS, 2010, p. 19). Ou seja, apontamos para uma nova concepção da causa do martírio, sugerindo que havia, além do modelo causado pelas perseguições, um discurso de si dos primeiros cristãos que valorizava o sofrimento, este semelhante ao de Jesus.

Imitar a Cristo é um tema recorrente na literatura cristã; as atividades e ensinos de Jesus tornaram-se modelos para a vida cristã. A imitatio Christi perpassa a literatura do Novo Testamento, além de algumas obras dos Pais da Igreja, demonstrando como os primeiros cristãos já se identificavam com o tema do sofrimento e imitação de Cristo, e a base para a construção dessa representação do cristão como sofredor, potencializada mais tarde na literatura do cristianismo primitivo do II e III século d.C. (PERKINS, 1995, p. 32).

Ao assimilar o mártir a Cristo, altera-se de forma extraordinária o seu status aos olhos de sua audiência, dotando-o de poder semelhante ao de Cristo. Tal assimilação englobava não apenas a maneira de sua morte, como também a função salvadora de Jesus e seu status divino (MOSS, 2010, p. 47).

A apresentação dos mártires feita pelas atas, como perfeitos imitadores de Cristo, possibilitou que a morte do mártir fosse vista como exemplo para suas audiências. O mártir como modelo criou uma cadeia de imitação, inspirando não apenas pessoas a aceitarem a Cristo, mas a conversão ao martírio. Em síntese, o martírio gerou martírio (MOSS, 2010, p. 102).

O mártir é, assim, apresentado em um primeiro momento como um verdadeiro imitador de Cristo; em um segundo momento, ele se torna um modelo de imitação. Por fim, pela semelhança com Cristo, é transformado discursivamente numa personagem que está acima dos demais cristãos comuns e até mesmo dos anjos. Eles recebem imortalidade, são coroados, recompensados, são entronizados no céu, juízes escatológicos, profetas visionários, intercessores. Eles não são apenas garotos do coro no céu; eles são realeza, eles pertencem a uma nova categoria de sujeito. 


\section{Morte voluntária?}

Esse personagem - que é uma explosão de poder - criado pelos próprios cristãos primitivos contribuiu para uma desesperadora corrida à gloria como mártir. Essa categoria ficou conhecida como martírio voluntário. Esse modelo não agradou a todos, principalmente os apologistas da Igreja como, por exemplo, Clemente de Alexandria, que desqualificou como falsos os mártires "que corriam para a morte" (MIDDLETON, 2014, p. 123).

Para G. Bowersock (1995, p. 3), “esse fenômeno de martírio voluntário não era de modo algum uma excentricidade do período: ele continuou por mais de um século". Alguns exemplos de martírios voluntários são listados em sua obra, dentre eles um relato conservado por Eusébio de um grupo considerável de cristãos mortos no Alto Egito, no quarto século.

Então, contemplamos o admirável ardor, o poder verdadeiramente divino, a coragem dos que acreditaram no Cristo de Deus. Pois, enquanto se pronunciava a sentença contra os primeiros, alguns acorriam de outro lado para o tribunal, diante do juiz. Declaravam-se cristãos, sem se inquietarem por causa dos tormentos nem das diversas espécies de suplícios aos quais se expunham; mas falavam com inteira liberdade, corajosamente, da religião do Deus do universo e recebiam alegres, risonhos, bem-humorados a sentença final de morte, cantando hinos e dando graças ao Deus do universo até o último suspiro (EUSÉBIO DE CESAREIA, 2000, p. 411).

Bowersock (1995, p. 18) destaca no exemplo proposto por Eusébio que a "maioria destes foram voluntários, e logo que um deles fora condenado, saltaram um após o outro diante do tribunal para confessar-se cristãos". Todavia, com o tempo, houve uma investida por parte de apologistas cristãos, tais como Clemente de Alexandria, Orígenes, Cipriano e Lactâncio, na tentativa de impedir esse entusiasmo e reservar a classificação de mártires para aqueles que suportaram sofrimento e morte em face da perseguição:

Na época de Cipriano, na metade do terceiro século, a Igreja já tinha começado um vigoroso esforço para desencorajar martírios voluntários e reservar a coroa do mártir para aqueles cuja fé foi verdadeiramente testada pelas autoridades seculares.

Clemente não se dispõe apenas a diferenciar o que constituiria "verdadeiro" ou "falso" martírio, mas afirma que tais não fazem parte de seu grupo, embora compartilhassem o nome cristão e fossem executados oficialmente como os demais mártires.

Paul Middleton (2014, p. 123) sublinha que essa prática, embora rejeitada por alguns, tornou-se comum entre os primeiros cristãos e nos mais diversos 
textos do cristianismo primitivo. Tertuliano, destaca Middleton, ao contrário de Clemente, não diferencia martírio voluntário daquele por perseguição, mas considera-os como atos verdadeiros dos mártires (2014, p. 124).

Em sua obra $A d$ Scapulam, Tertuliano evidencia sua visão acerca dessa modalidade. A propósito do evento ocorrido na Ásia, onde cristãos se apresentaram diante do procônsul exigindo martírio, ele responde ao procônsul:

Sua crueldade é nossa glória. Apenas veja isso, tendo em tais coisas como essas suportar, nós não nos sentimos constrangidos a correr adiante para o combate, se apenas para provar que não temos medo deles, mas, pelo contrário, até mesmo convidar sua inflição (Ad Scapulam 5,1).

Em seu artigo, Willian Tabbernee (1985, p. 33-44) classifica a posição contrária ao martírio voluntário como ortodoxa2, uma posição eclesiástica. $\mathrm{O}$ autor questiona a imagem projetada do movimento montanista como um grupo de "pessoas obcecadas por um desejo imprudente pelo martírio e uma atitude intransigente em relação ao Estado". Ele sugere, também, que a Igreja e seus representantes, desde muito cedo, desaprovaram a modalidade voluntária, atitude que crescia entre os primeiros cristãos, principalmente entre os montanistas.

O mártir era escolhido por Deus para realizar tal feito mediante uma visão que o alertava de que esse era seu destino. Entretanto, essas visões são registradas tanto antes quanto depois da prisão, como sugere Tabbernee (1985, p. 34):

Uma vez presos, a maioria dos cristãos louvava a Deus por terem sido considerados dignos de serem testados dessa maneira e tentavam assegurar aquela coroa do mártir, nessa fase, não os iludiram através da "utilidade" de seus amigos, sua própria covardia, ou a timidez do agente de execução.

Mesmo se recebessem a visão anteriormente citada, eles não deveriam se entregar às autoridades; no entanto, não mais evitariam a prisão a partir daquele momento.

Existiram casos de martírios voluntários específicos que foram aceitos pela ortodoxia. Muitos cristãos foram presos e, por conseguinte, muitos deles receberam a revelação/visão de Deus, sinal da escolha deles para o martírio; contudo, alguns apostataram. Diante de tais casos, alguns cristãos espectadores que acompanhavam os processos condenatórios dos companheiros

2 Termo cunhado por Tabbernee para designar os apologistas e a posição da Igreja, que confrontaram esse tipo de martírio. 
mostraram-se solidários e procuraram encorajá-los a não negarem a fé, ocasionando, muitas vezes, sua prisão juntamente com os demais condenados. Nesses casos, afirma Tabbernee (1985, p. 35):

Como a ação desses homens era altruísta, na medida em que buscavam a coroa do mártir para os outros, isso não era condenado como martírio voluntário. Acreditava-se que Deus, ao dar a essas pessoas a coragem de falar, significava que eles, também, foram escolhidos para o martírio.

O outro tipo de situação em que o martírio voluntário foi aceito pela Igreja se direciona aos cristãos que apostataram na perseguição de Décio. Um dos editos propostos pelo imperador exigia que todos os cidadãos do império oferecessem sacrifício aos deuses de Roma; assim receberiam um certificado testificando o cumprimento de sua ordem. Alguns cristãos, ao saber do edito do imperador, prontamente compareceram diante das autoridades para cumpri-lo; outros conseguiram os certificados sem realizar o sacrifício.

Por fim, diante das autoridades, alguns não suportaram os flagelos e acabaram apostatando. Esses apóstatas não foram readmitidos na Igreja. Uma única maneira de ser recebido de volta seria repudiando estas petições; assim poderiam cancelar sua apostasia. Se, ao fazê-lo, eles chamassem a atenção levando ao martírio, a Igreja não condenaria sua ação, mas a trataria como uma exceção necessária.

\section{A imagem obscura dos cristãos}

Nos dois primeiros séculos as comunidades cristãs eram malvistas pela sociedade romana por não participarem das reuniões e eventos cívicos. Por causa de suas "abominações" e "ódio da raça humana", como afirma Tácito, foram acusados de serem os causadores de problemas circunscritos, tais como o incêndio de Roma no ano 64, e por isso foram perseguidos. Houve, também, uma imparcialidade por parte da jurisprudência romana, tendo em vista que, por um lado, utilizavam de mecanismos punitivos para que os cristãos acusados perante o imperador negassem o nome de Cristo e sacrificassem aos deuses, e, por outro, os cristãos não poderiam ser acusados anonimamente e perseguidos pelas autoridades romanas, como demonstrado na correspondência de Plínio a Trajano.

Não há como determinar, antes do terceiro século, quais foram as leis que fundamentaram a perseguição aos cristãos por parte dos romanos. Dentre as possibilidades, Luis Alberto de Boni (2014, p. 135-168) reconhece três opiniões diferentes na pesquisa. 
A primeira opinião, citada pelo autor, afirma que tal prática contra os cristãos se baseou numa legislação especial, um senatus consultum ou um edito imperial. Para De Boni (2014, p. 140), essa teoria não se sustenta por dois motivos: primeiramente, Tertuliano menciona em sua obra Apologeticum 4,7 "uma antiga e confusa floresta de leis" utilizadas contra os cristãos. Por fim:

ela também não explica por que até o edito de Décio, em 250, só houve esporádicas ações contra os cristãos e por que também os demais autores cristãos, que sustentaram a existência de uma lei persecutória, não souberam citar qual foi esta lei. Além disso, as normas eram dirigidas para questões específicas em determinadas regiões, sendo aplicadas conforme a intenção do governante. De Boni sugere a aplicação da legislação sobre crime comum, a Lex iulia de majestate, a única lei da qual os funcionários públicos poderiam se valer para condenar os cristãos. Todavia, "a Lex iulia não se voltava especificamente contra os cristãos", mas era "destinada a punir os rebeldes" (DE BONI, 2014, p. 141).

Uma segunda opinião via a perseguição como um castigo devido à recusa dos cristãos, por inertia, pertinácia ou obstinatio, a celebrar os cultos tradicionais de Roma. Esse procedimento teria ocorrido com mais frequência nas províncias, atesta De Boni (2014, p. 142-143), e os trâmites judiciais não eram utilizados para essa categoria de condenação, ficando a cargo dos governantes, mediante a coerção, manter a ordem pública.

Uma terceira posição aceita nos últimos tempos pela maioria dos estudiosos, atesta o autor, compreende esse ato hostil como punição por parte do poder policial em defesa da ordem pública. Assim:

Os cristãos eram punidos, portanto, pelo direito penal comum, do qual os funcionários se valiam para impor a pena que julgassem cabível, e os cristãos seriam então punidos não pelo fato de serem cristãos, mas por violarem as leis romanas, como nos crimes de ateísmo, lesa-majestade, magia, superstição e os flagitia, isto é, atos torpes, como incesto, infanticídio, refeições onde se servia carne humana, rituais de morte etc. (DE BONI, 2014, p. 142).

Paradoxalmente, se num primeiro momento a causa da hostilidade aos cristãos foi motivada por motins e levantes locais, e os imperadores não tinham relações diretas com elas, no terceiro e quarto séculos estes passaram a desempenhar um papel importante nas ações persecutórias.

A partir do segundo século, aponta Uiara Otero, as práticas religiosas particulares de estrangeiros foram consideradas superstitio, que enquadravam 
rituais noturnos, em que se deduzia a promiscuidade sexual, deboches, violações ou incestos, assim como rituais secretos, que permitiam suspeitar de infanticídio ou antropofagia, e foram lidos como uma suposta conjuração vinculada ao juramento e sacrifício humano.

Um processo de repressão de tais práticas se intensificou com o imperador Septímio Severo (193-211), que viu em tais grupos uma ameaça para a religião tradicional. O imperador promulgou um edito no ano de 202 proibindo judeus e cristãos de fazerem proselitismo, reprimindo os pagãos de se converterem a essas religiões sob pena de graves castigos (COMBY, 1993, p. 46). Soma-se a isso o cisma por ocasião das comemorações do aniversário de seu reinado. Os cristãos negaram-se a prestar culto ao imperador, reanimando a perseguição por parte das autoridades locais na Ásia, norte da África e na Itália (DE BONI, 2014, p. 157). Sofreram martírio nesse tempo o bispo Irineu; Leônidas, pai de Origines, em Alexandria; Perpétua e Felicidade, em Cartago; e o Papa Zeferino, em Roma (GONZÁLEZ, 1995, p. 135; COMBY, 1993, p. 46; DE BONI, 2014, p. 157).

É digno de nota que não somente os cristãos eram monitorados, mas magos, filósofos, astrólogos além de egípcios e judeus, que eram conhecidos como freelance expert em religião (OTERO, p. 187). Severo foi extremamente cruel em relação à magia, astrologia e sonhos proféticos, ameaçando de morte aqueles que possuíam manuais de magia, bem como aqueles que fossem pegos realizando tais atos mágicos (WYPUSTEK, 1997, p. 276).

Esses dados nos oferecem uma possibilidade: se as práticas cristãs se enquadravam na categoria de superstitio e freelance expert em religião, como sustenta Otero, é possível afirmar que os romanos consideravam as práticas de tais grupos semelhantes e, consequentemente, ameaçadoras, o que nos autoriza dizer que a imagem que os romanos tinham dos cristãos do império era de um grupo misterioso que possuía conhecimento de astrologia, magia e conceitos sobrenaturais; e, além disso manipulavam tais elementos e conhecimentos a seu favor, tornando-se uma ameaça para o império. A seguir, passaremos à procura de evidencias em textos martirológicos que possam amparar nosso argumento.

\section{Visiones or superstitiones magicae? Os mártires como agentes sobrenaturais}

Para Andrzej Wypustek (1997, p. 277), dentre os mais diversos grupos cristãos que surgiram nos primeiros dois séculos da era cristã, o movimento 
montanista foi o que mais aproximou os cristãos das superstitiones magicae aos olhos dos romanos.

O montanismo foi um movimento que se originou na Frígia, sudoeste da Ásia Menor, no segundo século da era cristã ${ }^{3}$, cujo principal expoente foi Montano. As informações acerca de Montano são escassas. Sabemos que ele viveu na Frígia, durante o segundo século d.C., ensinou uma nova revelação e reivindicou poderes proféticos, reunindo muitos discípulos, dentre eles mulheres.

"Nova Profecia" era como os membros desse novo movimento do cristianismo primitivo identificavam a si mesmos. "Montanismo" foi atribuído a eles no século IV d.C. por Ciro de Jerusalém (315-86), ao negar sua filiação ao cristianismo (TREVETT, 2002, p. 2). Eles primitivamente também foram conhecidos como catafrígios, designando a fundação geográfica do movimento, e priscillianistas e quintillianistas, referindo-se às outras líderes femininas do movimento, Priscilla e Quintilla (EUSÉBIO DE CESARÉIA, 2000, p. 259).

As informações a respeito do movimento de Montano são mínimas, pois são produtos de debates e apologias que carregam uma desaprovação de seus adversários. Todavia, há evidências suficientes para traçar as principais características do movimento. A liderança mais conhecida identificada com a Nova Profecia foi a de Montano, Priscilla e Maximilla; porém, outros líderes foram importantes para o crescimento do movimento, dentre eles Quintilla e Teódoto, sendo que o segundo era responsável pelo setor financeiro e assumiu a liderança após a morte de Montano. Já a primeira, segundo Rex D. Butler, foi uma profetisa visionária que gerou uma facção dentro do montanismo chamada "Os Quintillianos" (BUTLER, 2006, p. 11). Além da Frígia e Ásia Menor, o montanismo se espalhou rapidamente até chegar ao Ocidente, e na província romana de Cartago atraiu seu principal expoente na região, Tertuliano (BUTLER, 2006, p. 14).

Os montanistas afirmavam ter uma intima relação com o Espírito Santo, cuja aproximação lhes rendeu uma nova revelação, bem como inspiração para suas profecias. A profecia extática foi a forma assumida no montanismo, e essa forma profética associada ao êxtase atraiu muita atenção e hostilidade. De acordo com Christine Trevett, os "críticos católicos estavam suficientemente preocupados por um modelo de expressão que era estranho e estava evidentemente unido (eles pensavam) com a irracionalidade" (TREVETT, 2002, p. 89). Para os pagãos, lembra-nos Wypustek (1997, p. 277), superstitio

3 Não há um consenso na pesquisa quanto à data precisa do surgimento do movimento, tendo em vista a escassez de informações existentes sobre eles. Há quem atribua a origem do movimento aos anos 130-150 d.C. e quem acredite que o movimento surgiu entre 160-170 (cf. BUTLER, 2006, p. 14). 
era um sinal de delirium, deliramentum, de insanidade. Em transe, os Montanistas recebiam revelações escatológicas. O conhecimento do futuro por intermédio do transe religioso é bem documentado nos 'Papiros Mágicos Gregos' (PMG). Assim, a glossolalia montanista poder ser confundida com as voces magicae 4 dos PGMs.

Os montanistas eram muito rigorosos com relação à vida sexual. Eusébio nos fornece uma crítica feita por Apolônio, uma de suas fontes. Dentre as obras e ensinamentos de Montano elencados por Apolônio, encontram-se duas máximas referentes ao casamento: 1) que ele ensinou a "dissolver casamentos"; e 2) que as profetisas do movimento, possivelmente se referindo a Priscilla e Maximilla, "depois que ficaram repletas do espírito, abandonaram os maridos".

São essas suas declarações sobre Montano. Relativamente às suas profetisas, mais adiante escreve: "Mostramos, pois, que essas primeiras profetisas, depois que ficaram repletas do espírito, abandonaram os maridos. Como, pois, não mentem ao dar a Priscila o nome de virgem?” (HE 5.18.3) (EUSÉBIO DE CESARÉIA, 2000, p. 259-260).

O montanismo se orgulhava de seus mártires. As perseguições eram vistas por eles como demonstração da presença do Paracleto e como um sinal do fim dos tempos. Essa expectativa escatológica do final, juntamente com a esperançosa crença na descida da Jerusalém celestial, contribuiu para criação de um discurso de dever, instigando cristãos a confessarem sua fé em público. Para Frederick C. Klawiter (1980, p. 253):

Se a esperança apocalíptica é interpretada como uma imagem política, então não é surpreendente que o desejo pelo martírio ou o que tem sido chamado de martírio voluntário fosse uma característica importante na Nova Profecia. A presença da esperança apocalíptica e do martírio claramente indica que a condição opressiva de perseguição criou a atmosfera na qual a chama da Nova Profecia ardeu de forma resplandecente.

Outro aspecto importante era o status que o mártir adquiria perante sua audiência. Como sublinhado acima, o montanismo era extremamente rigoroso em suas disciplinas e não concedia indulto aos membros batizados que cometessem certos tipos de pecado, pois não havia perdão para eles. Entretanto, existia uma única solução para esses pecadores: o contato com

\footnotetext{
4 Voces magicae são palavras mágicas sem sentido lexical aparente que aparecem com frequência nos textos dos PGM. Seu caráter é misterioso, mas indispensável na concretização e realização dos feitiços nos textos dos PGM. Ver: CARDOSO, Patricia Schilithler da Fonseca. Voces Magicae: O poder das palavras nos Papiros Gregos Mágicos. 2016. Dissertação (Mestrado em Letras Clássicas) - Universidade de São Paulo, 2016.
} 
mártires ou com os cristãos confessos que aguardavam a morte. Aqueles que aguardavam a morte poderiam exercitar e/ou manifestar grande poder, além de um poder especial apontado por Klawiter (1980, p. 254):

Eles ainda tinham o poder das chaves, isto é, o poder de perdoar os pecados daqueles que tinham negado a fé e, portanto, pensavam ter perdido a salvação. Ao exercer esse poder de perdoar, o mártir era capaz de restaurar uma pessoa negligente de volta à comunhão com Cristo e com a Igreja.

$\mathrm{Na}$ iminência do sofrimento os mártires experimentavam visões carismáticas, sonhos proféticos e poderes sobrenaturais. Tais manifestações de poder, frieza diante da morte, desprezo pela tortura ou condenação, certa veneração por parte dos demais fiéis contribuíram para a construção de uma imagem exótica e ameaçadora dos mártires cristãos.

A hermenêutica montanista influenciou profundamente na construção da identidade dos cristãos na África do Norte, onde as perseguições de Severo foram mais cruéis. Um dos mais importantes relatos de martírio do Norte da África, e do cristianismo primitivo, a Passio Sanctorum Perpetuae et Felicitatis (A Paixão das Santas Perpetua e Felicidade), apresenta seus protagonistas como cristãos ideais, dotados de poderes sobrenaturais.

Por volta da virada do segundo para o terceiro século (202-204), Perpétua, Felicidade, Revocato, Saturnino e Secundulo foram presos na cidade de Thuburbu Minus, em Cartago, Norte da África, durante o reinado do imperador Septímio Severo (Passio 2). Dentre os catecúmenos, Perpétua e Felicidade são apresentadas como personagens principais do relato de martírio. Perpétua era de família importante, e casada. Sua família é brevemente apresentada no relato: pai, mãe e dois irmãos. Ela era muito jovem e acabara de dar à luz uma criança (Passio 2,3).

O núcleo do relato (3-10) é atribuído a Perpétua, escrito em primeira pessoa. Nesse bloco, ela registra uma série de ocorrências que aconteceram com seus companheiros catecúmenos enquanto aguardavam julgamento e execução. Dentre as informações registradas por ela constam: sonhos oraculares; oração intercessora por uma criança que morreu na tenra idade; encontros dramáticos com seus familiares - incluindo a ansiedade e tristeza pela ausência de seu bebê recém-nascido; e o julgamento e sentença ad bestias.

Os capítulos restantes (1-2;11-21) são atribuídos a um(a) redator anônimo. Nesse bloco temos os registros: de visões atribuídas a Sáturo, que é identificado como o líder espiritual do grupo (11-13); o aceleramento do parto de Felicidade (15), que possibilitou sua execução com seus companheiros; e a execução dos mártires na arena. 
Perpétua é constantemente representada - direta e indiretamente - como porta-voz do grupo de cristãos cartaginenses. Em todo o relato há uma ênfase na capacidade concedida por Deus a ela, habilitando-a a questionar e confrontar o sistema patriarcal romano, representado pela figura de seu pai e do procurador Hilariano (Passio 3, 6,9).

Ela tem poder no submundo, terra e céu. Seu poder é inexplicável aos olhos dos pagãos, inclusive de seu pai. Sua postura - assim como dos mártires em geral, supomos - faz com que os habitantes de Cartago suspeitem que ela, juntamente com seus companheiros, estava sob influência de práticas magicas, bem como realizava tais práticas a seu favor. Seu pai não compreende as atitudes de sua filha, que prefere desprezar a família por uma nova e suspeita superstitio, o que pode indicar que esteja enfeitiçada por um hipnotizador cristão profissional, talvez Sáturo líder dos catecúmenos (WYPUSTEK, p. 284).

Na prisão havia um alvoroço e preocupação por parte do tribuno, que temia a fuga dos mártires pela utilização de magia: "estavam tratando-os com uma crueldade especial porque, com base no que foi dito por algumas pessoas tolas, ele estava com medo de que eles seriam sequestrados da prisão por algum encantamento mágico [...] (Passio 16,2).

No antigo império romano havia uma alta taxa de mortalidade infantil. Uma pequena expectativa de sobrevivência de crianças e mães nos trabalhos de parto, bem como a precariedade da vida, o período da gravidez e o momento do parto, assim como as crianças recém-nascidas, provocaram uma supervalorização destas. Da mesma forma, eram vistas como carentes de proteção, pois, para os romanos, elas eram alvos de investidas de poderes ocultos e demônios. Com o intuito de afastar tais poderes ameaçadores, foram confeccionados diversos amuletos e ritos mágicos, principalmente de magia uterina.

A magia uterina consiste na proteção do útero contra poderes e demônios invocados para prejudicar a gravidez, causando, por exemplo, abortos, escorrimentos e danos à criança e à mãe. A magia uterina também era utilizada para controlar o tempo da abertura e o fechamento do útero, ou seja, o solicitante pode utilizar a magia para ajudar o curso natural da concepção, gravidez e parto; para evitar um aborto espontâneo, um nascimento prematuro (AUBERT, 1989, p. 421-430). Contudo, a magia uterina poderia ser usada, também, de forma negativa, para acelerar o processo de abertura do útero, causando, portanto, ou um aborto ou aceleramento do parto. O PGM LXII. 76-106 nos fornece um exemplo de abertura de útero: 
"Que as genitálias e o útero dela, NN, sejam abertos, e que ela sangre noite e dia". E [essas coisas devem ser escritas] em sangue de ovelha e recitadas antes do amanhecer, as ofertas / (?) ... primeiro ela sofre, ... e enterre-o perto sumagre ou próximo... em um pedaço de papiro.

Por ocasião do martírio, Felicidade se encontrava impedida de ser lançada na arena com seus companheiros mártires por causa de sua gravidez. A situação é resolvida mediante a aceleração do trabalho de parto (Passio 15,1-7).

O relato oferecido pela Passio evidencia a crença entre os cristãos de que, assim como no mundo greco-romano, o útero se constituía como uma entidade à parte do corpo e, da mesma forma, poderia ser controlado por meio de imprecações, conjuros e magia. O útero de Felicidade poderia ser aberto mediante a intervenção da oração dos mártires.

\section{Considerações finais}

Procuramos problematizar o conceito de martírio e perseguição no cristianismo primitivo. Evitamos a supervalorização da ideia de uma perseguição generalizada e buscamos explorar os variados modelos de martírio coexistentes nos primeiros séculos da era cristã. Isso nos fez apontar para o julgamento e condenação dos mártires, que num primeiro momento foram condenados por tumultos e como causadores de desordem. Contudo, tal acusação é intensificada no início do segundo século, quando passaram a ser julgados e condenados por crimes contra a religião. A obscura imagem construída pelos romanos fez com que eles fossem enquadrados numa categoria que ocupavam também os magos, filósofos, astrólogos, egípcios e judeus. Quanto aos mártires, especificamente montanistas e cartaginenses, evidenciam práticas que, aos olhos dos romanos, eram idênticas àquelas dos magos, por isso eram temidas e coibidas. Assim, sugerimos que, a partir do segundo século da era cristã, tal imagem contribuiu para a perseguição e execução de mártires no império romano, em especial no Norte da África.

\section{Referências bibliográficas}

AUBERT, Jean-Jacques. Threatened wombs: aspects of Ancient Uterine Magic. Greek-Roman and Byzantine Studies, n. 30, p. 421-449, 1989.

BETZ, Hans Dieter. The Greek Magical Papyri in translation, including the Demotic Spells. Vol. One: Texts. Chicago; London: The University of Chicago Press, 1992.

BOWERSOCK, G.W. Martyrdom and Rome. Cambridge: Cambridge University Press, 1995. 
BUTLER, Rex D. New prophecy \& new visions: evidence of Montanism in The Passion of Perpetua and Felicitas. Washington: The Catholic University of America Press, 2006.

CARDOSO, Patricia Schilithler da Fonseca. Voces magicae: o poder das palavras nos Papiros Gregos Mágicos. 2016. Dissertação de Mestrado em Letras Clássicas. São Paulo: Universidade de São Paulo, 2016.

COMBY, Jean. Para ler a História da Igreja: das origens ao século XV. Vol. 1. São Paulo: Loyola, 1993.

DE BONI, L. A. O estatuto jurídico das perseguições dos cristãos no Império Romano. Trans/Form/Ação, Marília, v. 37, p. 135-168, 2014.

DE STE CROIX, G. E. M. Why were the Early Christians persecuted? Past and Present, n. 26, p. 135-168, 1963.

DE STE. CROIX, G. E. M. Christian persecution, martyrdom, and orthodoxy. Edited by Michael Whitby and Joseph Streeter. New York: Oxford University Press, 2006.

EUSÉBIO DE CESARÉIA. História Eclesiástica. São Paulo: Paulus, 2000.

GONZÁLEZ, Justo L. E até os confins da terra: uma história ilustrada do Cristianismo. Vol. 1. São Paulo: Vida Nova, 1995.

KLAWITER C., Frederick. The role of martyrdom and persecution in developing the priestly authority of women in Early Christianity: a case study of Montanism. Church History: Studies in Christianity and Culture, 49, Issue 03, p. 251-261, September, 1980.

MIDDLETON, Paul. What is martyrdom? Mortality, v. 19, n. 2, p. 117-133, 2014.

MOSS, Candida. The myth of persecution: how Early Christians invented a story of martyrdom. New York: Harper Collins, 2013.

MOSS, Candida. The other Christs: imitating Jesus in Ancient Christian ideologies of martyrdom. New York: Oxford Press, 2010.

NOGUEIRA, Paulo A. S. Narrativa e cultura popular no Cristianismo Primitivo. São Paulo: Paulus, 2018.

OTERO, Uiara Barros. Os mártires latinos de Cartago: as fronteiras entre o lícito e ilícito (202-258 E.C). 2017. Tese de Doutorado em História. Rio de Janeiro: Universidade Federal do Estado do Rio de Janeiro, 2017.

PERKINS, Judith. The suffering self: pain and narrative representation in the Early Christian Era. London: Routledge, 1995.

TABBERNEE, Willian. Early Montanism and voluntary martyrdom. Colloq, n. 17, p. 33-44, 1985.

TABERNEE, Willian. Fake prophecy and polluted sacraments: ecclesiastical and imperial reactions to Montanism. Leiden: Brill, 2007 (Supplements to Vigiliae Christianae 84).

TREVETT, Christine. Montanism: gender, authority and new prophecy. Cambridge: Cambridge University Press, 2002.

WYPUSTEK, Andrzej. Magic, Montanism, Perpetua, and the severan persecution. Vigiliae Christianae, v. 51, n. 3, p. 276-297, 1997.

Submetido em: 27-2-2020

Aceito em: 23-4-2020 